DOI: 10.12797/Politeja.12.2015.39.05

\title{
Lotar RASIŃSKI
}

Dolnośląska Szkoła Wyższa

lotar.rasinski@dsw.edu.pl

\section{GENEALOGIA JAKO KRYTYKA: HABERMAS VS. FOUCAULT}

\section{ABSTRACT Genealogy as critique: Habermas vs. Foucault}

The aim of this paper is to respond to the objections raised by Jürgen Habermas in his work The Philosophical Discourse of Modernity against Michel Foucault's concept of genealogical critique. In my response I draw primarily on Foucault's methodological texts and I demonstrate the strong connections of his ideas to the French historical epistemology of Gaston Bachelard and Georges Canguilhem. This connections concern mainly the ideas of the „recurrent method” and the "history of error” developed in this tradition. I argue that these ideas refute Habermas' allegations against Foucault's view of history (presentism) as well as his approach to the problem of truth (relativism). At the concluding part of my paper I focus on Foucault's concept of freedom, emphasizing the practical and „anti-romantic" character of this concept and its connection to the Marxian idea of emancipation (the objection of cryptonormativism).

Keywords: Michel Foucault, Jürgen Habermas, social criticism, genealogy, archeology of knowledge

Słowa kluczowe: Michel Foucault, Jürgen Habermas, krytyka społeczna, genealogia, archeologia wiedzy 
$\mathrm{J}$ ednym z najbardziej spektakularnych sporów XX-wiecznej filozofii jest dyskusja na temat krytyki, władzy i nowoczesności między Jürgenem Habermasem a Michelem Foucaultem. Jak wiadomo, jest to jedynie wirtualna wymiana poglądów, która nigdy nie przybrała realnych kształtów, choć w rozmaity sposób próbowano ją rekonstruować1. Obaj filozofowie mieli w planach spotkanie na neutralnym gruncie amerykańskim $^{2}$, do którego wszakże nie doszło z powodu nagłej śmierci Foucaulta w 1984 roku. Dlatego debata między nimi, która kontynuowana była przez komentatorów u schyłku minionego stulecia, przybrała dość jednostronny charakter i była prowadzona językiem narzuconym przez Habermasa. Stało się tak, gdyż to Habermas wprost odniósł się krytycznie do Foucaulta, poświęcając jego koncepcji krytyki i władzy dwa rozdziały Filozoficznego dyskursu nowoczesności $i^{3}$, sam Foucault natomiast, poza zdawkowymi uwagami rozrzuconymi w różnych wywiadach i artykułach, nigdy nie zajął się filozofią Habermasa w sposób poważny. Kilkakrotnie wypowiadał się o zadziwiającym nieprzenikaniu się dwóch postaci myśli wyjątkowo sobie bliskich ${ }^{4}$ oraz kurtuazyjnie chwalił szkołę frankfurcką za wytyczenie szerokich dróg, których wcześniejsza znajomość pozwoliłaby mu zapewne uniknąć opowiadania tylu gtupstw oraz krażenia po bezdrożach ${ }^{5}$. Nie ma jednak wątpliwości, że za pobieżnymi podobieństwami, jakich można się doszukać między myślą Foucaulta a teorią krytyczną, kryją się głębokie różnice, nie tylko w pojmowaniu krytyki i roli intelektualisty, ale także w pojmowaniu wiedzy i rozumieniu współczesnego świata.

Celem tego artykułu jest próba odpowiedzi na zarzuty wobec koncepcji krytyki Foucaulta wysunięte przez Habermasa w Filozoficznym dyskursie nowoczesności. Zarzuty te, w moim przekonaniu, ukazują rzeczywiste problemy, z którymi musiał zmagać się Foucault, formułując główne postulaty swej metody. Nie uważam jednak tak jak Habermas, że projekt krytyczny Foucaulta jest chybiony i pozbawiony siły emancypacyjnej. Wręcz przeciwnie, twierdzę, że projekt ten jest nie tylko możliwy i ważny praktycznie, ale i wolny od pewnych teoretycznych słabości koncepcji Habermasa, związanych przede wszystkim z elitarystyczną ideą porozumienia racjonalnych jednostek jako uniwersalnego fundamentu krytyki społecznej. Staram się wyjaśnić wątpliwości Habermasa, odwołując się przede wszystkim do metodologicznych prac Foucaulta oraz wskazując na jego silne związki z francuską tradycją historii epistemo-

Zob. Critique and Power. Recasting the Foucault/Habermas Debate, red. M. Kelly, Cambridge, Mass. 1994, Studies in Contemporary German Social Thought; Foucault Contra Habermas. Recasting the Dialogue between Genealogy and Critical Theory, red. D. Owen, S. Ashenden, London-Thousaund Oaks 1999.

2 Zob. M. Foucault, Strukturalizm i poststrukturalizm, [w:] tenże, Filozofia, historia, polityka. Wybór pism, przeł. D. Leszczyński, L. Rasiński, Warszawa-Wrocław 2000; por. J. Habermas, Taking Aim at the Heart of the Present, [w:] Critique and Power..., s. 150.

3 Zob. J. Habermas, Filozoficzny dyskurs nowoczesności, przeł. M. Łukasiewicz, Kraków 2000, wykład IX i X, Horyzonty Nowoczesności, t. 9.

4 M. Foucault, Strukturalizm i poststrukturalizm, s. 302.

5 Tamże. 
logicznej reprezentowaną przez Gastona Bachelarda i Georges’a Canguilhema. Związki te pozwalają zarówno wyjaśnić kwestię spojrzenia na historię z teraźniejszej perspektywy, jak i ukazać specyficzny stosunek Foucaulta do kwestii prawdy. W końcowej części artykułu przedstawiam koncepcję wolności Foucaulta, starając się podkreślić jej praktyczny i „antyromantyczny” charakter, a także pewną zbieżność z emancypacyjnym projektem Marksa.

\section{ZARZUTY}

Trzy główne zarzuty Habermasa wobec koncepcji krytyki i władzy Foucaulta przedstawione w Filozoficznym dyskursie nowoczesności dotycząprezentyzmu, relatywizmu i normatywizmu ${ }^{6}$. Co do prezentyzmu Habermas twierdzi, że genealogiczna historiografia, którą uprawia Foucault, jest w swym nastawieniu antyhermeneutyczna i dlatego stroni od prób zrozumienia tego, co myślą i czynią „aktorzy”, na podstawie fuzji tradycji i ich samorozumienia. Celem Foucaulta jest natomiast wyjaśnienie horyzontu, który w ogóle umożliwia pojmowanie działań jako sensownych, przy uwzględnieniu praktyk leżacych u ich podstaw ${ }^{7}$. Tego można wszak dokonać, przyjmując perspektywę zewnętrzną, gdyż same zdarzenia są pozbawione sensu, który nadają im kalejdoskopowe przemiany uniwersów dyskursywnych. Zdaniem Habermasa Foucault nie jest jednak w stanie utrzymać tego rodzaju obiektywności i musi popaść w hermeneutyczną sytuację wyjściowa, gdyż nawet radykalny historysta może wyjaśnić techniki wtadzy i praktyki panowania tylko we wzajemnym porównaniu, a bynajmniej nie każda z osobna jako totalność samaz sie$b i e^{8}$. W konsekwencji historyczne studia Foucaulta muszą zakładać podziały na epoki, które implicite odniesione są do teraźniejszości. To czyni z niego, można powiedzieć, kryptohermeneutę. A zatem Foucault mimowolnie uprawia prezentyzm.

Drugi zarzut Habermasa dotyczy relatywizmu koncepcji Foucaulta. Polega on, jak stwierdza Habermas, na autoreferencjalnej negacji roszczeń do ważności ${ }^{9}$. Genealogiczna historiografia zakłada empiryczną analizę praktyk władzy, co ogranicza roszczenia do ważności do dyskursów, w których praktyki te występują, a ich sens sprowadza do $u d z i a t u$ samopotwierdzaniu się danego uniwersum dyskursywnego ${ }^{10}$. Jednakże Habermas zaznacza, że owa przesłanka Foucaultowskiej teorii władzy ograniczająca roszczenia do ważności do poszczególnych dyskursów odnosi się do samej tej teorii, tzn. musi ona podważać także podstawy ważności tych badań, które sama inspiruje. Innymi słowy, upada wobec tego podstawowe przedsięwzięcie Foucaulta, polegające na demaskacji zbankrutowanych nauk humanistycznych i stworzeniu w ich miejsce nowej nauki, która w jakiś sposób by je przewyższała. Foucault posługuje się zdyskwalifikowanymi

Zob. J. Habermas, Filozoficzny dyskurs nowoczesności, s. 315.

Tamże, s. 316.

Tamże.

9 Tamże, s. 326.

10 Tamże, s. 318. 
rodzajami wiedzy, pojawiającymi się $\mathrm{w}$ doświadczeniach różnego rodzaju uciśnionych grup - wiedzy, która, nie będąc oficjalną, nigdy nie mogła być wyartykułowana (strażnicy i więźniowie, pacjenci psychiatryczni i pielęgniarze, kobiety i czarownice itd.). Dyskursy te stawiają opór władzy, a genealogia, wynosząc je do poziomu wiedzy uczonej, stawia się po stronie uciśnionych jako przeciw-wtadza. Według genealogów, w przekonaniu Habermasa, ów zabieg pozwala rozszerzyć ich perspektywę i wykroczyć poza roszczenia do ważności, które konstytuują się tylko wewnątrz obszaru władzy, co umożliwia uzyskanie wyższości nad innymi rodzajami wiedzy. Jednakże Foucault w tym samym momencie sam sobie zaprzecza - bo przecież nie ma uprzywilejowanych dyskursów, a każda przeciw-władza, kiedy zdobędzie władzę, sama zaczyna tworzyć kompleks władzy, który stanie się wyzwaniem dla nowej przeciw-władzy. W ten sposób genealogia dokonuje swoistego relatywistycznego autodementi.

Trzeci zarzut Habermasa dotyczy kryptonormatywizmu. W założeniach Foucaulta historiografia genealogiczna całkowicie odrzuca normatywne roszczenia do ważności i w sposób czysto opisowy analizuje uniwersa dyskursywne. Jedną z podstawowych idei Foucaultowskiej teorii władzy jest przekonanie o produktywności władzy, co nie pozwala opisywać jej w jedynie negatywnych kategoriach, a tego, co władzy poddane, traktować jako „wyższe” czy „lepsze” od niej samej. Nie ma żadnej wtaściwej strony, po której należałoby się opowiedzieć. Wypływająca stąd aksjologiczna neutralność nie jest jednak dla Habermasa autentyczna. Foucault jest od samego początku zaangażowanym intelektualistą, uważa się za dysydenta, który stawia opór nowoczesnemu myśleniu i humanistycznie przebranej wtadzy dyscyplinowania ${ }^{11}$. Cała jego koncepcja jest podporządkowana krytycznemu gestowi, aż po styl pisarstwa i dobór słów. Foucault stara się wyjść poza znane opozycje charakterystyczne dla nowoczesnych gier językowych: autonomia-heteronomia, moralność-legalność, emancypacja-represja, i swego oporu przeciwko władzy nie chce tłumaczyć poprzez odwrócenie obrazu istniejącej władzy. Dysydencja czerpie jedyne usprawiedliwienie swego oporu stąd, że zastawia putapki na bumanistyczny dyskurs, nie wdajac się weñ ${ }^{12}$. Nie ma tutaj zupełnie zastosowania analogia do marksowskiej krytyki ideologii, gdyż władza Foucaulta odciska się raczej w ciałach, a nie w świadomości, a zatem krytykowanie ideologii traci sens. Genealogia będzie zatem raczej taktyką prowadzenia wojny przeciwko władzy, której nie da się zaatakować normatywnie, gdyż ta normatywnych podstaw nie posiada. Habermas, powołując się notabene na Nancy Fraser ${ }^{13}$, zapytuje wobec powyższego, co w ogóle sprawia, że podejmowanie walki jest lepsze od uległości, dlaczego mielibyśmy przeciwstawić się dominacji. Zdaniem Habermasa nie znajdujemy u Foucaulta jasnej odpowiedzi na to pytanie. Jedyną sensowną odpowiedzią jest przyznanie, że potępienie władzy musi się brać z przyjęcia pewnych założeń normatywnych: Gdy jednak spróbujemy z elokwentnych oskarżeń dyscyplinujacej wtadzy wydobyć stosowane implicite kryteria, odnajdziemy znane określenia

11 Tamże, s. 321.

12 Tamże, s. 322.

13 Zob. N. Fraser, Foucault on Modern Power. Empirical Insights and Normative Confusions, [w:] Critical Essays on Michel Foucault, red. P. Burke, Aldershot 1992, Critical Thought Series, 2. 
pochodzace $z$ explicite odrzucanej, normatywistycznej gry jezzykowej ${ }^{14}$. Foucaulta oburza przecież asymetryczna relacja władzy oraz reifikujące skutki technik władzy. Tym samym krytyka Foucaulta staje się stronnicza ${ }^{15}$, a jednocześnie nie jest w stanie wykazać swych normatywnych podstaw.

Poświęciłem tyle miejsca zreferowaniu zarzutów Habermasa dlatego, że rzeczywiście przedstawiają one, choć w nieco wykrzywionym świetle języka normatywizmu Habermasa, zasadnicze elementy Foucaultowskiej koncepcji krytyki. Zarzuty te sprowadzają się właściwe do wykazania błędnego koła w rozumowaniu, polegającego na samoznoszeniu się krytyki Foucaulta, co można podsumować następująco: Paradygmat Foucaulta, wedtug Habermasa, (a) jest "nieuchronnie zwiazany z wtasna hermeneutyczna sytuacja wyjściową", (b) zaprzecza istnieniu jakichkolwiek uniwersaliów (być może $z$ wytaczeniem paradoksalnego uniwersalium gtoszącego, że nie ma uniwersaliów), oraz (c) odwotuje się do norm krytycznych, których nie da się uzasadnić, ponieważ uzasadnienie wymaga uniwersaliów ${ }^{16}$.

Można powiedzieć, że według Habermasa dwa podstawowe pojęcia koncepcji Foucaulta - władza i krytyka - wzajemnie się wykluczają, gdyż władza jest u niego czymś, co poprzedza, i jednocześnie czymś, co podważa krytykę.

\section{HERMENEUTYCZNA SYTUACJA WYJŚCIOWA (PREZENTYZM)}

Jeśli można przyjąć jako zasadne zarzuty relatywizmu i kryptonormatywizmu - w sensie takim, że są to rzeczywiste problemy teoretyczne, z którymi w pewien sposób Foucault musiał się zmagać - to zdumiewa mnie zarzucanie Foucaultowi prezentyzmu. Foucault wykazuje, zdaniem Habermasa, uporczywe roszczenie do obiektywności ${ }^{17}$, zapomina jednak, że cały czas patrzy ze swojej perspektywy, zanurzony w dniu dzisiejszym, co Habermas łączy z niemożliwością ucieczki od perspektywy hermeneutycznej, nieodzownie zakładającej pewną sytuację wyjściową. Zarzut ten jest moim zdaniem całkowicie chybiony. Po pierwsze, hermeneutykę krytykuje Foucault w nieco innym kontekście, niż zdaje się to sugerować Habermas. Po drugie, Foucault nigdy nie określał metody archeologicznej w kategoriach „obiektywności” jako spojrzenia wstecz, które wyzbywa się teraźniejszej perspektywy. Wręcz przeciwnie, nawiązywał raczej do francuskiej tradycji historii epistemologicznej, która od Gastona Bachelarda walczyła z obiektywizmem w historii pod hasłem ,analizy rekurencyjnej”. Mamy tu więc do czynienia ze „zdumiewającym nieprzenikaniem się" pokrewnych koncepcji w obie strony - Habermas całkowicie ignoruje tradycję, z której wywodzi się myśl Foucaulta.

Aby wyjaśnić tę kwestię, należy wyjść zatem od rzeczy podstawowej - tradycji teoretycznej, do której odwołuje się Foucault. Powszechne jest przyczepianie mu etykiet,

\footnotetext{
J. Habermas, Filozoficzny dyskurs nowoczesności, s. 324.

Tamże, s. 315.

16 M. Kelly, Foucault, Habermas, and Self-Referentiality of Critique, [w:] Critique and Power..., s. 365.

17 J. Habermas, Filozoficzny dyskurs nowoczesności, s. 316.
} 
które niezmiernie go irytowały - strukturalisty, poststrukturalisty, kryptomarksisty czy postmodernisty, albo przedstawianie go jako teoretyka społecznego, literata czy teoretyka literatury spod znaku transgresji, psychologa czy socjologa. Niewątpliwie z każdą z tych etykiet coś go łączy. Niemniej on sam konsekwentnie wpisuje się raczej we francuską tradycję historii epistemologicznej, którą nazywa filozofią wiedzy, racjonalności i pojęcia przeciwstawianą filozofii doświadczenia, sensu i podmiotu, reprezentowanej przez Jeana-Paula Sartre’a czy Maurice'a Merleau-Ponty'ego ${ }^{18}$. Jak sam pisze w La Vie. L'expérience et la science, mniej znanym tekście, będącym wprowadzeniem do angielskiego wydania Le normal et le pathologique Canguilhema: Powszechnie wiadomo, że we Francji jest jedynie kilku logików, a za to wielu wybijajacych sięfilozofów nauki. Powszechnie wiadomo także, że w filozoficznej instytucji - edukacyjnej czy badawczej - to oni zajmuja pierwszoplanowa pozycje ${ }^{19}$.

Wypowiedzi te nie są bynajmniej, jak uważa wielu komentatorów, swoistą „biograficzną kokieterią” czy „autokreacją” Foucaulta. Był on przecież wychowankiem historyka wiedzy Georges’a Canguilhema, który prowadził go przez jakiśs czas w akademickiej karierze oraz pełnił funkcję kogoś w rodzaju promotora przy jego dysertacji doktorskiej $^{20}$.Za najwybitniejszą postać filozofii francuskiej starszego pokolenia Foucault uważał Gastona Bachelarda i nieprzypadkowo większość jego książek to właśnie „historie”, wśród których wyjątkiem jest Archeologia wiedzy, będąca wszakże opisem metody analizy historycznej. W jednym z wywiadów, opisując powojenną panoramę intelektualną Francji, Foucault próbuje zdystansować się od ruchu, który nazywa freudo-strukturalo-marksizmem, stwierdzając: Myślę o tych, którzy zajmowali się historiq nauki będąca we Francji od czasów Comtéa tradycja bez wątpienia znaczaca i skupiona wokót Canguilhema, na uniwersytecie francuskim [...] postaci wptywowej. Otóż wielu z jego uczniów nie byto ani marksistami, ani zwolennikami Freuda, ani strukturalistami. I mówię tu, jeśli pan pozwoli, o sobie $e^{21}$.

W tradycji francuskiej, począwszy od Bachelarda, panuje przekonanie, że w najlepszy sposób możemy poznać rozum ludzki poprzez badanie nauki, a samą naukę poprzez refleksję nad jej historią. Bierze się to z przeświadczenia, że struktury rozumu ujawniają się nie w abstrakcyjnych zasadach, ale w konkretnych zastosowaniach rozumu. To nauka ksztatci rozum. Rozum musi być postuszny nauce ${ }^{22}$ - twierdzi Bachelard. Badanie rozumu naukowego doprowadza go do wniosku, że historia nauki nie rozwija się w sposób ciągły i jednolity, ale pełno w niej raptownych przerw i zerwań (koncepcja coupure épistémologique $)^{23}$, oraz że nie ma czegoś takiego jak historia „nauki w ogólności”,

18 Zob. M. Foucault, La Vie. L'expérience et la science, „Revue de métaphysique et de morale” 1985, nr 1, s. 4. Korzystam tu z wydania oryginalnego, ale jest też tłumaczenie polskie: tenże, Życie. Doświadczenie i nauka, [w:] tenże, Filozofia, historia, polityka...

19 Tenże, La Vie..., s. 3. Tłumaczenia tekstów obcojęzycznych, jeśli nie zaznaczono inaczej: L. Rasiński. Zob. D. Eribon, Michel Foucault. Biografia, przeł. J. Levin, Warszawa 2005, s. 143, 145 i in.

21 M. Foucault, Strukturalizm i poststrukturalizm, s. 299.

22 G. Bachelard, Filozofia, która mówi nie. Esej o filozofii nowego ducha w nauce, przeł. J. Budzyk, Gdańsk 2000, s. 148, Minerwa.

23 Zob. np. G. Bachelard, Le nouvel esprit scientifique, Paris 1968; tenże, Le rationalisme appliqué, Paris 
jest raczej historia różnych obszarów pracy naukowej. Cięcia epistemologiczne nie zachodzą jedynie między historycznymi odmianami poszczególnych teorii naukowych (np. między fizyką Newtona a Einsteina), ale także na bardziej podstawowych poziomach: między wiedzą potoczną a naukową, między różnymi filozofiami, odpowiadającymi typom poznania naukowego (empiryzm i racjonalizm) czy między różnymi rozumieniami czasu. Dlatego też u Bachelarda pojawia się przekonanie, że nie da się odkryć na podstawie historii nauki pojęcia jednej, monolitycznej racjonalności ludzkiej, ale raczej trzeba mówić o różnych obszarach racjonalności [les régions rationelles] ${ }^{24}$, mających odniesienie do różnych obszarów nauki.

Najistotniejszym jednak elementem koncepcji Bachelarda w kontekście jego związków z Foucaultem jest przekonanie o rekurencyjnym charakterze refleksji historycznej. W jego rozumieniu historia, w przeciwieństwie do klasycznych ujęć, ale także np. historyków zgrupowanych wokół pisma "Annales”, ma charakter nieciągły i pluralistyczny, a przede wszystkim musi się wyzbyć opisywania zdarzeń z perspektywy „,zasu kosmicznego”. Obiektywność tradycyjnej historii polegająca głównie na opisie tego, jak rzeczy się miały i co ludzie myśleli, ale bez próby oceny owych zdarzeń i myśli, jest według Bachelarda niemożliwa, a w każdym razie nie do przyjęcia w historii nauki. Historia rekurencyjna [histoire récurrentielle] ${ }^{25}$ polega zatem na spojrzeniu na przeszłość nauki z perspektywy dnia dzisiejszego, tzn. tego, co obecnie uznaje się w nauce za racjonalne. Inne spojrzenie na historię nauki nie miałoby sensu. Historyk nauki, będący zarazem epistemologiem, musi oddzielić od siebie to, co z przeszłości nauki pozostaje wciąż aktualne, od tego, co zostało odrzucone i stanowi przeszkodę epistemologiczna [obstacle épistémologique ${ }^{26}$. Oddzielenie od siebie owych dwóch rodzajów zdarzeń naukowych wymaga pewnego osądu, refleksji nad minionymi teoriami z perspektywy dzisiejszego stanu wiedzy. W tym sensie historia nauki jest dialektyką błędu i prawdy, która opisuje zwycięstwa racjonalizmu i porażki irracjonalizmu ${ }^{27}$. Opis błędów i przeszkód epistemologicznych może być więc czasem równie ważny jak opis tego, co uznano za prawdziwe, gdyż nie można założyć, że dojdziemy do jakiegoś momentu absolutnej prawdy, który zakończy rozwój nauki. Prawda naukowa jest tymczasowa i ograniczona do konkretnej dziedziny. Ma status doraźnego „punktu widzenia”, który na jakiś czas wyznacza kierunek rozwoju wiedzy.

Foucault przejmuje założenia historii rekurencyjnej od Bachelarda najprawdopodobniej przez Canguilhema, z którym stykał się w École normale supérieure i którego

1949 i wiele innych prac. Jak wiadomo, momenty rozłamowe są ważnym elementem prac Foucaulta: pojawienie się pierwszej nowoczesnej powieści (Stowa i rzeczy), pierwsza obserwacja ciała pacjenta (Narodziny kliniki), dzień, w którym uwolniono pacjentów z Bicêtre czy nagłe zniknięcie Statku Szaleńców (Historia szaleństwa) lub przekształcenie spektaklu tortur publicznych (Nadzorować i karać). Zob. G. Bachelard, Le rationalisme appliqué, rozdział 7.

25 Pojęcia tego używa Canguilhem, powołując się na Bachelarda, zob. G. Canguilhem, La formation du concept de réflexe aux XVIIe et XVIIIe siècles, Paris 1957, s. 166.

26 G. Bachelard, Ksztattowanie sie umystu naukowego. Przyczynek do psychoanalizy wiedzy obiektywnej, przeł. i posł. D. Leszczyński, Gdańsk 2002, s. 22, Minerwa.

27 Zob. D. Leszczyński, K. Szlachcic, Wprowadzenie do francuskiej filozofii nauki. Od Comtéa do Foucaulta, Wrocław 2003, s. 200-203, Acta Universitatis Wratislaviensis, nr 2493. 
prace, jak pisał Foucault po latach w liście do Canguilhema, odcisnęty piętno ${ }^{28}$ na jego myśli, począwszy od La Naissance de la clinique. Na początku Archeologii wiedzy wymienia zresztą obu myślicieli (oprócz nich jeszcze Michela Serresa’a i Martiala Gueroulta) jako tych, którzy dokonali przełomu w myśleniu o historii, kierując swą uwagę z dtugich okresów czy wielkich catości na elementy roztamowe $e^{29}$. Wspomina tam także Canguilhema jako tego, który wskazał podziaty rekurencyjne ujawniające w tej samej nauce kilka przesztości, występujące wraz z przekształcaniem się jej teraźniejszości ${ }^{30}$. Opisy historyczne podporządkowuja się przeto nieuchronnie aktualności wiedzy, mno$\dot{z} a$ się, gdy ta ulega kolejnym transformacjom i same z kolei przecza sobie wzajemnie ${ }^{31}-$ podsumowuje.

Trudno więc stwierdzić, że Foucault uważa swoją metodę archeologiczną za metodę obiektywnego oglądu historycznego. Można próbować co najwyżej sugerować, że zakłada on jakiś obiektywizm, ponieważ wypowiada się krytycznie o hermeneutyce, co z pewnością nie podoba się Habermasowi. Rzeczywiście Foucault odnosi się w Archeologii wiedzy do hermeneutyki krytycznie. Samego słowa „hermeneutyka” w całej książce używa bodaj dwukrotnie, przy opisie kategorii wypowiedz $z^{32}$ oraz przy analizie możliwości porównań pomiędzy różnymi formacjami dyskursywnymi $i^{33}$. Krytykuje ją także kilkakrotnie nie wprost, mówiąc, przy okazji rozprawy z pojęciem dzieta jako tradycyjną kategorią jedności dyskursu, o dyskursie bezcielesnym, gtosie cichym jak tchnienie, pótmilczeniu, które poprzedza dyskurs i jest w nim obecne $e^{34}$. Wszędzie chodzi mniej więcej o to samo - o określenie tego, czym jest, a może raczej - czym nie jest, wypowiedź, będąca podstawową jednostką dyskursu.

Dlaczego zatem wypowiedzi nie da się interpretować zgodnie z zasadami hermeneutyki? Habermas przekonuje, że Foucault chce wyjšć poza prezentystyczna świadomość czasów [...], skąd wynika metodologiczna konsekwencja porzucenia hermeneutyki ${ }^{35}$. Trudno się z tym zgodzić. Zdaniem Foucaulta przedmiotem archeologii jest jawność rzeczywistego jezyka $a^{36}$. Wypowiedź ma być czymś, co już nastąpiło, ale czego nie da się uchwycić percepcyjnie jak przedmiot materialny, gdyż jest ona uwikłana w sieć zewnętrznych relacji, które nie muszą być bezpośrednio jawne. Foucault stwierdza także jednak, że

28 Zob. D. Eribon, Michel Foucault..., s. 143.

29 Zob. M. Foucault, Archeologia wiedzy, przeł. A. Siemek, wstęp J. Topolski, Warszawa 1977, s. 28-29, Biblioteka Myśli Wspótczesnej. Plus Minus Nieskończoność. kiem na nią łączy np. Foucaultowskie odrzucenie kategorii dzieła i autora jako elementów organizują-
cych dyskurs czy zamianę dokumentów w zabytki. Por. J. Habermas, Filozoficzny dyskurs nowoczesności,

35 Tamże, s. 285.

36 s. 285-286.

Zob. tamże, s. 29.

Tamże.

Tamże, s. 142.

Tamże, s. 199.

M. Foucault, Archeologia wiedzy, s. 142. 
analiza wypowiedzi musi brać pod uwagę zjawisko rekurencji ${ }^{37}$. Oznacza to, że odrzucając hermeneutykę, nie odrzuca bynajmniej spojrzenia z perspektywy teraźniejszości. Archeologia opisuje stosunki, w jakie wchodzą wypowiedzi, które nie mają charakteru wewnętrznego, nie odwołują się do sensu czy znaczenia wypowiedzi, lecz do stosunków zewnętrzności czy też - jak to nazywa Foucault - pozytywności: opisać zbiór wypowiedzi nie w odniesieniu do wnętrza intencji, myśli czy podmiotu, lecz zgodnie z rozproszeniem zewnętrznościs $i^{38}$.

Jest to miejsce bardzo ważne w Archeologii wiedzy. To właśnie tam pojawia się określenie szczęśliwy pozytywista, które skwapliwie wykorzystuje Habermas i którego kilkakrotnie z premedytacją używa w Filozoficznym dyskursie nowoczesności. Gdy jednak przytoczy się całą wypowiedź Foucaulta i jego wyjaśnienie, na czym owa pozytywność miałaby polegać, przypisywanie mu pozytywizmu - bo to prawdopodobnie głównie kryje się pod tym, co Habermas rozumie przez obiektywizm - okaże się, moim zdaniem, co najmniej nadużyciem. Przede wszystkim Foucault posługuje się tym stwierdzeniem w znaczeniu ironicznym. Jak wiemy, zarówno początek, jak i koniec Archeologii wiedzy wyznacza dialog z wyimaginowanymi krytykami, którzy są niezadowoleni z przedstawionych przez Foucaulta rozwiązań i domagają się dopowiedzeń i wyjaśnień, stawiają zarzuty, np. dotyczące tego, że nie udaje mu się uniknąć strukturalizmu. $Z$ dużym prawdopodobieństwem można stwierdzić, że przyjęcie przez Foucaulta etykiety szczęśliwego pozytywisty - a nie nazwanie siebie (!) - ma raczej status kolejnego dialogu z krytykami, którzy chętnie będą chcieli mu przyczepić miano „pozytywisty”: Jeśli zamiana dociekania totalności na analize rozrzedzenia, zamiana motywu transcendentalnego podtoża na opis stosunków zewnętrzności, zamiana poszukiwania początku na analizę kumulacji oznacza postawe pozytywistyczna, zgadzam się tatwo na to, by mnie nazwano [podkr. L.R.] szczęśliwym pozytywistą ${ }^{39}$. Innymi słowy, z dwojga złego Foucault woli być już raczej „przezywany” pozytywistą niż hermeneutą ${ }^{40}$.

Warto zatem wyjaśnić, co Foucault ma na myśli, mówiąc o pozytywności dyskursu i wypowiedzi, a co w moim przekonaniu rozwiewa wszelkie wątpliwości na temat jego rzekomego pozytywizmu. Pozytywność gra [...] rolę czegoś, co można by nazwać historycznym a priori ${ }^{41}$. A priori ma tu oznaczać nie warunek prawdziwości sądów, ale warunek realności wypowiedzi. Chodzi o a priori historii, która jest nam dana jako historia

\footnotetext{
Tamże, s. 159.
}

Tamże, s. 160 .

39 Tamże.

40 Por. J. Habermas, Filozoficzny dyskurs nowoczesności, s. 283. Jest tu pewien problem, gdyż jedynym miejscem, jakie Habermas podaje jako adres Foucaultowskiego odwołania się do szczéśliwego pozytywizmu, jest nie Archeologia wiedzy, ale L'ordre du discours, gdzie Foucault w dość mglisty sposób mówi o usposobieniu szcześliwego pozytywizmu [l'humeur d'un positivisme heureux] w kontekście genealogii i „wypracowanej nonszalancji” odniesionej do „stylu krytycznego”. Gdzie indziej jednak Habermas mówi już o Foucaulcie jako o szcześliwym pozytywiście bez podania adresu, mając zapewne na myśli Archeologię wiedzy. Zob. M. Foucault, Lordre du discours. Leçon inaugurale au Collège de France prononcée le 2 décembre 1970, Paris 1971, s. 72 (wyd. polskie: Porządek dyskursu. Wyktad inauguracyjny wygtoszony w Collège de France 2 grudnia 1970, przeł. M. Kozłowski, Gdańsk 2002, Minerwa).

41 M. Foucault, Archeologia wiedzy, s. 162. 
rzeczy naprawdę powiedzianych ${ }^{42}$. Ów poziom, na którym można uchwycić pewne regularności w pojawianiu się wypowiedzi i zawierający w sobie wszystkie czynniki mające udział w formowaniu się wypowiedzi, Foucault nazywa archiwum: Jest to ogólny system formowania się i przeksztatcania wypowiedzi $i^{43}$. To niewątpliwie pewien Kantowski moment w koncepcji archeologii, ale przede wszystkim jednak moment Bachelardiański. Foucault chce powiedzieć, że w każdą refleksję historyczną uwikłana jest nasza teraźniejszość, dlatego aprioryczność podtoża dyskursywnego wypowiedzi nie ma charakteru transcendentalnego ${ }^{44}$, ale jest uwarunkowana historycznie, tzn. zmienia się wraz ze zmianą stanu wiedzy oraz tego, co ją otacza, a co Foucault nazywa czynnikami niedyskursywnymi. Jest to oczywiście również mocno niezgodne z tym, co Kant mówił na temat apriorycznych form poznania. Odwołanie się do aprioryczności jest jednak niewątpliwie znaczące i wprowadza tu faktycznie pewien rys Kantowski. Foucault rozjaśnia nieco tę kwestię w Réponse à une question, gdzie mówi o prawie istnienia wypowie$d z i$, tego, co je umożliwito - je i nic innego; warunkach ich pojedynczego pojawienia się ${ }^{45}$. Foucault proponuje tu więc, jeśli można tak powiedzieć, transcendentalizm Kantowski bez uniwersalnej ważności albo coś w rodzaju „aposteriorycznej aprioryczności” ${ }^{4}$. Jeśli dobrze rozumiem Foucaulta, to warunki możliwości pojawienia się wypowiedzi można zbadać jedynie post factum, w innym przypadku mielibyśmy do czynienia ze spekulacją lub z metafizyką. Jest to właściwie nic innego niż przekształcona nieco i odniesiona do innego przedmiotu analiza rekurencyjna Bachelarda i Canguilhema. Historię nauki można badać tylko z perspektywy dzisiejszej, a jej celem jest poznanie procesu (warunków), który doprowadził do obecnego stanu wiedzy. Tak samo Foucaultowskie analizy szaleństwa, narodzin medycyny czy nowoczesnego więziennictwa są w dużej mierze próbą uchwycenia warunków możliwości czegoś, co można nazwać dzisiejszą racjonalnością, tzn. tego, co doprowadziło nas, że myślimy dziś o sobie i o świecie tak, a nie inaczej. Uchwycenie warunków możliwości własnego sposobu myślenia zakłada pewien moment przygodności, gdyż wynika stąd, że to, jak myślimy, jest rezultatem splotu okoliczności, który mógł się potoczyć zupełnie inaczej. A to zakłada możliwość myślenia „w inny sposób”. Pozytywistyczne zasady neutralności podmiotu poznającego (także w sensie ahistoryczności), odrębności podmiotu i przedmiotu - nie mówiąc już o zasadzie empirycznej weryfikacji twierdzeń - a także wynikający z nich obiektywizm poznania (w rozumieniu pozytywistycznym, ale i Weberowskim), nie mogą tu być w oczywisty sposób spełnione.

42 Tamże.

43 Tamże, s. 165.

44 Habermas trafnie mówi o „słabej transcendentalności” archeologii.

45 M. Foucault, Réponse à une question, [w:] tenże, Dits et écrits, 1954-1988, Vol. 1, red. D. Defert, F. Ewald, Paris 1994, s. 681, Bibliothèque des Sciences Humaines. Jeszcze dobitniej wyraża to Foucault w L'ordre du discours, gdzie opisując regutę zewnętrzności organizującą badanie dyskursu, mówi on o zewnętrznych warunkach możliwości dyskursu. Zob. tenże, L'ordre du discours..., s. 55.

46 Habermas zdaje się to dostrzegać, pisząc o transcendentalnym historyzmie genealogii. Zob. J. Habermas, Filozoficzny dyskurs nowoczesności, s. 285. 


\section{RELATYWISTYCZNE AUTODEMENTI (RELATYWIZM)}

Ważnym elementem Foucaultowskiego projektu archeologii jest motyw zainteresowania się tematami odrzucanymi i pomijanymi w oficjalnym, racjonalnym dyskursie, który niezwykle mocno wiąże myśl Foucaulta z podstawowymi założeniami historii epistemologicznej - pojęciem „przeszkody epistemologicznej” Bachelarda i „historią błędu” Canguilhema. Odsyła nas to do kwestii prawdziwości w analizie archeologicznej, a pośrednio do zarzutu Habermasa dotyczącego relatywizmu historiografii genealogicznej. Foucault porusza ten problem bezpośrednio w La Vie. Lexpérience et la science, odwołując się do metody rekurencyjnej ${ }^{47}$ uprawianej przez swych nauczycieli. Częścią tej metody jest, jak już nadmieniłem, zwrócenie uwagi przez historyka nauki na tematy odrzucane jako nieracjonalne, błędne, fałszywe itd. Przybliżając „filozofię błędu” Canguilhema, Foucault stwierdza: Btąd jest źródtem tego, co tworzy myśl ludzka i jej historię ${ }^{48}$. Błąd nie jest czymś, co zostaje wyeliminowane przez niezmienną siłę prawdy, ale czymś, co jest zastąpione przez nowy sposób mówienia prawdy ${ }^{49}$. W tym sensie można powiedzieć, że błąd dla Canguilhema jest jedynie „starszym” sposobem mówienia prawdy. Nie jest z pewnością czymś ostatecznym, tak jak nie ma ostatecznej prawdy, gdyż ta jest nieustannie rewidowana i korygowana wraz z rozwojem nauki. To, co wydawało się błędem, może okazać się prawdą wraz z nowym, spektakularnym odkryciem naukowym ${ }^{50}$.

Takimi „błędami” w historii nowoczesnej racjonalności są z pewnością szaleństwo, ale także choroba, występek, zbrodnia, seksualność, czyli tematy, które Foucault porusza w swoich kolejnych pracach. Z pewnością odchodzi on od historii epistemologicznej w postaci charakterystycznej dla Bachelarda i Canguilhema. Bachelard zajmował się wszak fizyką i chemią, Canguilhem zaś głównie biologią czy „naukami o życiu”. Foucault przenosi natomiast ich rekurencyjny sposób uprawiania historii wiedzy na dalsze dziedziny, które nie są uznawane za naukowe w ścisłym sensie - „nauki o człowieku”, do których zalicza językoznawstwo, ekonomię i „nauki o życiu”, psychiatrię, psychologię, kryminologię, nauki prawne. Dokonuje on tego zabiegu celowo, gdyż interesuje go poziom nieco głębszy niż poziom dyskursu naukowego, który nazywa wiedzą ${ }^{51}$.

Foucault stwierdza wyraźnie w Archeologii wiedzy, że to archiwum decyduje, co jest uznane za błąd, a co za prawdę. Archiwum jest splotem historycznych relacji i praktyk, które umożliwiają pojawienie się wypowiedzi. Dlatego w perspektywie historycz-

Zob. M. Foucault, La Vie..., s. 9.

48

49 G. Canguilhem, Idéologie et Rationalité dans l'histoire des sciences de la vie, Paris 1977, s. 21, Problèmes et Controverses; por. M. Foucault, La Vie..., s. 9.

50 Nie jest to zresztą bynajmniej sprzeczne ze współczesnymi trendami w metodologii nauk, które głównie pod wpływem krytyki Poppera praktycznie zrezygnowały z terminu „weryfikacja” (verifiaction) na rzecz łagodniejszej „konfirmacji” (confirmation) nieodwołującej się do pojęcia prawdy w klasycznym sensie albo na rzecz odwrotnej procedury „falsyfikacji” (falsification).

51 M. Foucault, Archeologia wiedzy, s. 220. 
nej może być wiele prawd dotyczących jednego przedmiotu wiedzy, które w pewnym momencie mogą nawet być ze sobą niezgodne. Foucault stwierdza w Réponse à une question: Jestem pluralista ${ }^{52}$. W innych tekstach mówi o tym, że zawsze pisał jedynie fikcje, co nie oznacza bynajmniej, iż prawda nie istnieje, gdyż fikcyjny dyskurs może wywoływać efekty prawdy ${ }^{53}$.

Czy to wszystko świadczy o tym, że Foucault jest relatywistą i podważa przez to własną teorię? Przede wszystkim należałoby zapytać, czy Foucault zajmuje się teorią prawdy jako metodolog lub epistemolog. $Z$ całą pewnością nie zastanawia się on nad problemem tego, czym jest prawda lub jaki rodzaj poznania przynosi nam prawdziwą wiedzę, a jaki nie. Interesuje go raczej zupełnie inna - jak mi się zdaje - kwestia: jak to się dzieje, że nasze niektóre wypowiedzi zostaja uznane za prawdziwe lub fałszywe ${ }^{54}$. Archeologia mówi nam tylko, że nie decyduje o tym ani schowany głęboko sens owych wypowiedzi, „negocjowany” następnie w procesie interpretacji, ani adequatio między nimi a rzeczywistością, ani koherencja z innymi wypowiedziami, ale pewne historyczne okoliczności, które można dość konkretnie opisać i które można by nazwać reżimami prawdy bądź polityka prawdy ${ }^{55}$.

Nie sądzę więc, żeby Foucault wysunął twierdzenie przypisywane mu przez Habermasa, głoszące, że nie istnieje prawda bezwzględna. Takiego metodologicznego problemu Foucault po prostu nie podejmuje. Historyczne ukazywanie związków różnych nauk z otaczającymi je „instytucjami, zdarzeniami politycznymi, praktykami i procesami ekonomicznymi” ${ }^{\prime 6}$ nie jest zorientowane na wykazanie tego, że jakakolwiek prawda w sensie klasycznym czy innym nie istnieje, ale wręcz przeciwnie, jest raczej próbą zrozumienia, w jaki sposób to coś, co nazywane jest prawdą i co z pewnością istnieje w naszym społeczeństwie oraz odgrywa w nim tak istotną rolę dla zrozumienia czlowieka i jego racjonalności, za prawdę zostało uznane. Foucault jest, można rzec, jakkolwiek źle to brzmi, historykiem prawdy ${ }^{57}$. Podobnie Canguilhem badał procesy biologicznej normatywności ${ }^{58}$, które doprowadziły do uznania pewnych zjawisk za normalne, a in-

52 Tenże, Réponse à une question, s. 674.

53 Tenże, The History of Sexuality, [w:] tenże, Power/Knowledge. Selected Interviews and Other Writings, 1972-1977, red. C. Gordon, New York 1980, s. 193.

54 Nie staramy się [...] odkryć, co jest prawdziwe, a co fatszywe, co jest oparte na fundamentach, a co nie, co jest rzeczywiste, a co iluzoryczne, co naukowe, a co ideologiczne, co jest prawomocne, a co jest nadużyciem wtadzy. Próbujemy się natomiast dowiedzieć, jakie są stosunki, jakie można znaleźć powiąania pomiędzy mechanizmami przymusu a elementami wiedzy, na czym polega gra wzajemnego przekazywania i wspierania się, która między nimi się toczy. Powodują one, że wtadza oddziatuje na dany element wiedzy $w$ pewnym systemie, $w$ którym staje się on elementem prawdziwym, prawdopodobnym, mato prawdopodobnym lub fatszywym [...] (tenże, Qu'est-ce que la critique?, „Bulletin de la Société Française de Philosophie" 1990, Vol. 84, s. 48).

55 Tenże, Truth and Power, [w:] tenże, Power/Knowledge..., s. 112. Por. tamże, s. 131.

56 Tenże, Archeologia wiedzy, s. 199.

57 Zob. tenże, Historia seksualności, przeł. B. Banasiak, T. Komendant, K. Matuszewski, wstęp T. Komendant, Warszawa 1995, s. 146, Nowy Sympozjon.

58 Zob. G. Canguilhem, Normalne i patologiczne, przeł. i posł. P. Pieniążek, Gdańsk 1999, s. 189, Minerwa. 
nych za patologiczne. Jak wykazał, nie decydowały o tym kryteria wyłącznie naukowe, biologiczne, ale odwołanie się do pewnych wartości, do oceny własnego stanu przez organizm. Niemożliwość wykazania „obiektywnej patologii” nie podważa jednak sensu uprawiania nauki, ale jedynie pokazuje, że nauka nie jest izolowaną wyspą na morzu tego, co społeczne. W procesy naukowe wpisane są akty normatywne, należące do dziedziny, którą Foucault nazywa zależnościami pozadyskursywnymi ${ }^{59}$. Z pewnością Foucault nie jest zwolennikiem klasycznej koncepcji prawdy (podobnie zresztą jak Habermas), ale nie można też stwierdzić, że w jakiś szczególny sposób pojęcie prawdy zwalcza czy że wyrzuca je ze swego słownika. Można powiedzieć nawet, że prawda go w pewien szczególny sposób intryguje, ale jedynie o tyle, o ile staje się elementem badanej formacji dyskursywnej.

\section{PARADOKSALNA KOMBINACJA NASTAWIENIA POZYTYWISTYCZNEGO I ROSZCZEŃ KRYTYCZNYCH (KRYPTONORMATYWIZM)}

Kiedy czytamy genealogiczne opisy praktyk dyscyplinarnych w Nadzorować $i$ karać oraz zmagania rozumu z nierozumem w Historii szaleństwa, w naturalny sposób nasuwa się pytanie, które słusznie zadał Habermas - czy przedstawione przez Foucaulta obrazy mają mieć walor czysto deskryptywny, czy też mają pełnić funkcję krytyczną. Jeśli genealogia ma być krytyką, to co miałaby ona oznaczać, co byłoby jej celem? Odpowiedzi nie znajdziemy w książkach Foucaulta, ale raczej w wykładach, pomniejszych artykułach oraz wywiadach, kiedy naciskany przez współrozmówców niechętnie musiał podjać się próby bezpośredniego odniesienia do własnego projektu krytycznego i poszukiwać sposobów na jego bardziej precyzyjne określenie. Tak dzieje się w przytaczanym już przeze mnie wywiadzie Strukturalizm i poststrukturalizm, w którym Foucault nie tylko zakreśla intelektualną trajektorię rozwoju swej myśli, ale spogląda z pewnym dystansem na stosowaną we własnych dziełach metodę. Nawiązując do Kanta i Nietzschego, mówi o kwestii teraźniejszości jako o podstawowym zadaniu filozofii i opisuje swą rolę jako genealoga: [...] jeśli chodzi o te funkcje diagnozująca, czym jest dzień $d z i-$ siejszy, to nie polega ona po prostu na stwierdzeniu, czym jesteśmy, lecz na tym, aby śledzac linie kruchości dzisiaj, postarać sięuchwycić, do którego momentu i w jaki sposób to, co jest, mogtoby nie być już tym, czym jest. I w tym wtaśnie sensie opis musi być zawsze dokonywany wedtug tego rodzaju możliwego pęknięcia, które otwiera przestrzeń wolności, rozumiana jako przestrzeń wolności konkretnej, czyli możliwego przeksztatcenia ${ }^{60}$. Jego zdaniem praca intelektualisty jako krytyka musi być czysto praktyczna. Ma polegać na mówieniu o tym, co jest, tak, jakby mogto nie być lub mogto nie być takie, jakie jest ${ }^{61}$. Genealogia ma ukazywać nam, że rzeczy, które wydają nam się najbardziej oczywiste, są wynikiem kon-

\footnotetext{
59 M. Foucault, Réponse à une question, s. 681.

60 Tenże, Strukturalizm i poststrukturalizm, s. 313.

61 Tamże.
} 
kretnych zdarzeń, często przypadkowych, że to, co jest teraz, nie zawsze byto, a zatem że nie musi być. Pokazanie takiej możliwości otwiera przestrzeń wolności i możliwej zmiany, pod warunkiem, że będzie to wolność konkretna [liberté concrète] ${ }^{62}$.

Zarzut Habermasa o ukrytym normatywizmie Foucaulta dotyczy rzeczywiście ważnego problemu związanego z każdym rodzajem krytyki, tzn. tego, czy warunkiem sensowności krytyki jest to, że musi mieć ona uniwersalną ważność. Habermas twierdzi, że Foucault, rezygnując z uniwersalnych roszczeń, fałszywie zakłada własną neutralność aksjologiczną, po cichu jednak zmuszony jest przyjąć jakieś normatywne zasady, chociażby takie, które pozwalają potępić reifikujące skutki władzy. Stąd Foucault jest nieświadomie stronniczy, a jego koncepcja staje się paradoksalna kombinacją nastawienia pozytywistycznego i roszczeń krytycznych ${ }^{63}$. Dla Habermasa po prostu krytyka pozbawiona podstaw normatywnych traci swoją moc i staje się bezskuteczna. Czy możliwe jest zatem uprawianie krytyki społecznej bez oparcia jej na normatywnych zasadach? Wydaje mi się, że - zapewne nie znosząc wszelkich wątpliwości - Foucault pokazuje, iż taki projekt jest do przeprowadzenia i nie musi być z góry skazany na niepowodzenie.

Zarzuty Habermasa nie są pozbawione racji w jednym przynajmniej punkcie. Cały teoretyczny pomysł Foucaulta opiera się w dużym stopniu na odniesieniu, w większości przypadków implicite, do pewnego ideału normatywnego - pojęcia „wolności”. Jak zauważa Barry Hindess, u Foucaulta istnieje gtęboki związek pomiędzy wtadzq a wolnościa $q^{64}$. Dla Habermasa podstawowym problemem koncepcji Foucaulta jest to, że ostrze krytyki genealogii stępione jest natychmiast przez uprzedniość i wszechobecność władzy, która wyklucza zasadność owej krytyki. Jego zdaniem tylko ugruntowana transcendentalnie czy komunikacyjnie krytyka może stać się podstawą prawdziwej emancypacji społecznej. Rzeczywiście mniej więcej do pierwszego tomu Historii seksualności Foucault kilkakrotnie posługiwał się zwrotami sugerującymi pewnego rodzaju „usubstancjalnienie” władzy ${ }^{65}$. Od początku lat 80 . można jednak dostrzec w koncepcji Foucaulta pewien zwrot, polegający na rezygnacji z idei wszechobecności władzy, którą eksploruje Habermas, co wiązało się właśnie z dostrzeżeniem relacji między władzą a wolnością.

Temat wolności, który w taki czy inny sposób towarzyszył Foucaultowi niemal od samego początku, po raz pierwszy wprost - jako problem genealogiczny - pojawia się w serii opublikowanych niedawno wykładów z Collège de France z 1978 roku, gdzie autor Historii seksualności zastanawia się między innymi nad kwestią „rządomyślności”

62 Zob. tenże, Structuralisme et poststructuralisme (rozmowa z G. Rauletem), „Telos” 1983, Vol. 16, nr 55, s. 206.

63 J. Habermas, Filozoficzny dyskurs nowoczesności, s. 309.

64 B. Hindess, Filozofie wtadzy. Od Hobbesa do Foucaulta, przeł. D. Leszczyński, L. Rasiński, WarszawaWrocław 1999, s. 110.

65 Wtadza jest wszędzie - nie dlatego, że wszystko obejmuje, ale dlatego, że zewsząd się wytania [...] wtadza nie jest ani instytucja, ani struktura, ani czyjąkolwiek potega; jest nazwa użczana ztożonej sytuacji strategicznej $w$ danym spoteczeństwie (M. Foucault, Historia seksualności, s. 83). Por. tenże, Trzeba bronić spoteczeństwa. Wyktady w Collège de France, 1976, przeł. M. Kowalska, Warszawa 1998, s. 39. 
[gouvernementalité $]^{66}$, „biopolityki” oraz liberalizmu. Rozważania nad liberalizmem, które pojawiają się pod koniec wykładu na temat „dyspozytywów [dispositifs ${ }^{67}$ bezpieczeństwa”, są tu szczególnie ciekawe, gdyż Foucault, zazwyczaj krytyczny wobec wszelkich ideologii politycznych, odnosi się do niego z pewną sympatią, choć niepozbawioną ironii ${ }^{68}$. Jako specyficzną sztukę rządzenia, liberalizm przenika zasada: „rządzenia zawsze zbyt wiele", badź też, trzeba zawsze podejrzewać, że rzadzenia jest zbyt wiele ${ }^{69}$. Wynika to oczywiście z paradoksalnego zadania, jakie wyznaczyła sobie myśl liberalna, $\mathrm{z}$ jednej strony przyznając wolności jednostki uprzywilejowane miejsce w stosunkach z państwem, z drugiej zaś - prowadząc refleksję nad możliwie największym ograniczeniem władzy państwa, przy jednoczesnym zapewnieniu mu największej skuteczności w realizowaniu celów przeznaczonych dla niego. Zdaniem Foucaulta liberalizm jako jedna z niewielu ideologii był w stanie dostrzec, że wolność jest po prostu pewną techniką rządzenia, która pozwala skuteczniej realizować dalekosiężne cele. Dlatego nie dotyczy ona jedynie prawa jednostki do przeciwstawienia się wtadzy, uzurpacjom $i$ nadużyciom suwerena lub rzadu, ale staje się elementem niezbędnym dla samej rzqdomyślności ${ }^{70}$. Warunkiem dobrego rządzenia jest - stwierdza Foucault - poszanowanie

66 Tenże, Techniki siebie, [w:] tenże, Filozofia, historia, polityka..., s. 249; por. tenże, About the Beginning of the Hermeneutics of the Self, „Political Theory” 1993, Vol. 21, nr 2, s. 204. Pozostaję tutaj przy tym tłumaczeniu słowa gouvernementalité, które kiedyś zaproponowaliśmy z Damianem Leszczyńskim (tenże, Rządomyślność, [w:] tenże, Filozofia, historia, polityka...). Sprawę rewidowania przekładu tego słowa, zwłaszcza w odniesieniu do niemieckich tłumaczeń, podniósł Michel Senellart w swoim posłowiu do Sécurité, territoire, population Foucaulta, gdzie wyjaśnia sposób utworzenia tego neologizmu (zob. tenże, Sécurité, territoire, population. Cours au Collège de France (1977-1978), Paris 2004, s. 406, Hautes Études). Nie przekonuje mnie to do rezygnacji z „rządomyślności” z trzech względów. Po pierwsze, łagodzenie na siłę nienaturalnego brzmienia tego słowa (jak „urządzanie” Michała Herera) zaciemnia zamysł Foucaulta, który próbuje nadać nazwę zjawisku do tej pory nienazywanemu i stąd próba „wymyślenia” nowego słowa. Gouvernementalité brzmi tak samo źle jak governmentality, Gouvernementalität czy rządomyślność, ale tak chyba miało być. Wiadomo skądinąd, że Foucault lubował się w tego typu neologizmach. Po drugie, rządomyślność to nie tylko nowa historyczna praktyka rządzenia, ale pewna koncepcja, sposób myślenia o rządzeniu, który pojawił się w Europie wraz z Machiavellim czy nieco po nim. Amerykańscy wydawcy Essential Works of Foucault, próbując uciec od nienaturalności tego terminu, stosują go naprzemiennie z „racjonalnościami rządzenia” (governmental rationalities, zob. C. Gordon, Introduction, [w:] M. Foucault, Power, red. J.D. Faubion, przeł. R. Hurley i in., New York 2000, s. XXV). A zatem element związany z „umysłowością”, „myśleniem” czy „racjonalnością" nie jest bynajmniej znaczeniowo obcy dla rozumienia tego terminu. I wreszcie po trzecie, w Polsce mamy sytuację specyficzną, gdyż jest pewna tradycja mówienia o „myślności” w związku ze słowem „prawomyślność”, co łagodzi nieco nienaturalność owego neologizmu. Prawomyślność oznacza po prostu „działanie w zgodzie z prawem” i na zasadzie analogii można zatem mówić o „rządomyślności” jako „działaniu, myśleniu w zgodzie z rządzeniem”.

67 Do tłumaczenia tego terminu w ten sposób przekonał mnie artykuł M. Nowickiej, „Urzadzenie”, „zastosowanie”, "uktad” - kategoria dispositif u Michela Foucaulta, jej ttumaczenia i ich implikacje dla postfoucaultowskich analiz wtadzy, „Przegląd Socjologii Jakościowej” 2011, Vol. 7, nr 2.

68 Zob. M. Foucault, Sécurité, territoire, population..., s. $49-50$ (wyd. polskie: tenże, Bezpieczeństwo, terytorium, populacja. Wyktady w College de France 1977/1978, przeł. M. Herer, Warszawa 2010).

69 Tenże, Naissance de la biopolitique, [w:] tenże, Résumé des cours, 1970-1982, Paris 1989, s. 111, Conférences, Essais et Leçons du Collège de France.

70 Tenże, Sécurité, territoire, population..., s. 361. 
wolności lub pewnych form wolności. Brak poszanowania wolności nie jest jedynie naruszeniem uprawnień pod względem prawnym, ale przede wszystkim jest nieznajomościa sztuki rządzenia ${ }^{71}$. Wolność w liberalizmie nie jest zatem pewnym normatywnym ideałem przynależącym jednostce z racji jej człowieczeństwa i niezbywalnego prawa do ochrony przed państwem. Liberalna racjonalność rządzenia zwraca uwagę na to, że bez wolnych decyzji jednostek nie da się realizować pewnych zadań wyznaczanych przez władzę.

Jak zatem widać Foucault odrzuca metafizyczne czy romantyczne rozumienie wolności, powiązane z wyzwoleniem jako realizacją głębokiej natury człowieka ${ }^{72}$. Czym miałaby być więc wolność konkretna, o której wspomina Foucault? W jednym ze swych późnych tekstów, który został załączony jako posłowie do książki Huberta Dreyfusa i Paula Rabinowa, Foucault wprost odnosi się do kwestii wolności i jej relacji do władzy: Wtadze sprawuje się nad wolnymi podmiotami i tylko o tyle, o ile sq wolne. [...] Wtadza i wolność nie moga spotkać się w bezpośredniej konfrontacji, która by je wzajemnie wykluczata (wolność zanika wszędzie, gdzie sprawuje się wtadze). Gra jest o wiele bardziej skomplikowana: wolność w niej może równie dobrze okazać się warunkiem sprawowania wtadzy [...]. Dlatego też istnieje nierozerwalna więź między wtadza. a niepostuszeństwem wolności. [...] W samym sercu stosunku wtadzy - stale go prowokując - leży krnąbrność woli i bezkompromisowość wolności ${ }^{73}$. Wolność jest zatem pewnym korelatem władzy. Foucault chce tutaj powiedzieć, że po pierwsze, nie ma czegoś takiego jak władza absolutna, która uniemożliwiłaby jakiekolwiek swobodne działanie. Tam, gdzie cztowiek jest $w$ tańcuchach, władzy nie ma, gdyż podstawą władzy jest możliwość wpływania na działania innych. Podmioty zawsze muszą dysponować jakimś polem możliwości dla różnych rodzajów zachowań czy reakcji. Po drugie, spoteczeństwo bez relacji wtadzy może być jedynie abstrakcją ${ }^{74}$. Tak samo jak niemożliwe jest totalne zniewolenie, tak też niemożliwe jest całkowite wyzwolenie, czyli wolność absolutna. Ten stan wykluczający obustronny paraliż władzy i wolności nazywa Foucault ,agonizmem”.

Francuski filozof odchodzi więc od sytuacji skrajnych, uniwersalnych, absolutnych - tak samo podejrzliwy jest wobec możliwości pełnej władzy, jak i pełnego wyzwolenia. W Qu'est-ce que les Lumières? Foucault dobitnie wyraża swoje kredo, dystansując się wobec wszelkich globalnych dyskursów obiecujących możliwość wydobycia ludzkości spod wszelkiej dominacji: Historyczna ontologia nas samych musi się odwrócić od wszelkich projektów, które roszcza sobie prawo do globalności i radykalizmu [...]. Wole bardziej konkretne transformacje, jakie nastapity w ostatnich dwudziestu latach $w$ kilku obszarach dotyczacych naszych sposobów bycia i myślenia, stosunków wtadzy, stosunków między ptciami, sposobów postrzegania szaleństwa i choroby, wolę nawet te częściowe

\footnotetext{
71 Tamże.

72 Por. C. Taylor, Foucault on Freedom and Truth, [w:] Foucault. A Critical Reader, red. D.C. Hoy, Oxford-New York 1986, s. 77.

73 M. Foucault, Subject and Power, [w:] H. Dreyfus, P. Rabinow, Michel Foucault. Beyond Structuralism and Hermeneutics, Chicago 1983, s. 221.

74 Tamże, s. 222-223.
} 
transformacje, które przebiegaty na styku analizy historycznej i postawy praktycznej, od obietnic nowego cztowiek a powtarzanych przez najgorsze systemy polityczne XX wieku ${ }^{75}$.

Widać tutaj wyraźnie, jak krytycyzm Foucaulta jest ściśle związany z doświadczeniem historycznym. W wykładzie Qu'est-ce que la critique?, który wygłosił Foucault dla Société française de philosophie w 1978 roku, stara się on wyjaśnić, dlaczego Kantowskie pytanie o oświecenie, które przybrało obecnie formę pytania o związki racjonalizacji z nadużyciami władzy, znalazło tak różne rozwinięcia we Francji i w Niemczech, stając się dla tych drugich podstawowym tematem filozoficznym aż do naszych czasów, zwłaszcza w kręgu „niemieckiej lewicy”, we Francji zaś było przez długi czas odsuwane na dalszy plan. Formacja utworzona przez oświecenie i rewolucję bez wątpienia powstrzymywata nas [...], by prawdziwie i gtęboko zakwestionować zwiazek pomiędzy racjonalizacją a wtadzą ${ }^{76}$. Doświadczenie rewolucji i jej związku z oświeceniem głęboko zapadło w pamięć intelektualistom francuskim i paradoksalnie to raczej francuskie nurty związane $\mathrm{z}$ "prawicą" na początku XX wieku zaczęły dostrzegać niebezpieczeństwa związane z wpływem, jaki wywiera na rozum władza. Dla Foucaulta owo historyczne doświadczenie myśli francuskiej zostało dodatkowo wzbogacone o wydarzenia XX wieku, w którym największe globalne projekty uzdrowienia ludzkości symbolizują stalinizm i faszyzm. Pytanie o Aufklärung powraca do Francji w XX wieku między innymi dzięki francuskiej krytyce fenomenologii przeprowadzonej przez historyków nauki ${ }^{77}$.

Dlatego projekt krytyczny Foucaulta musi mieć charakter ograniczony. Foucault, pomny doświadczeń francuskich, woli mówić nie o oświeceniu, ale raczej o „nowoczesności", nawiązując do znaczenia, jakie nadawał temu słowu Charles Baudelaire, dla którego była ona praktykowaniem wolności, polegającym na heroizowaniu teraźniejszości, przy jednoczesnym zachowaniu do niej ironicznego stosunku. Foucault proponuje potraktować nowoczesność nie jako okres historyczny, w którym uczestniczymy czy z którego mielibyśmy wyjść, ale raczej jako pewną postawę [attitude] wobec aktualności, która przypomina greckie êthos (albo włoskie virtü ${ }^{78}$ ). Êthos ten definiuje jako nieustanna krytykę naszego historycznego bycia ${ }^{79}$, której dokonuje się w trzech obszarach: specyficznego stosunku do teraźniejszości, odniesienia do historyczności oraz ustanawiania siebie jako autonomicznego podmiotu. Refleksja krytyczna, którą Foucault proponuje nazwać krytyka praktyczna [critique pratique] ${ }^{80}$, polegałaby na analizie i refleksji

75 M. Foucault, Qu'est-ce que les Lumières?, [w:] tenże, Dits et écrits, 1954-1988, Vol. 4, red. D. Defert, F. Ewald, Paris 1994, s. 574-575, Bibliothèque des Sciences Humaines.

76 Tenże, Qu'est-ce que la critique?, s. 43.

77 Zob. tamże, s. 44.

78 W Qu'est-ce que la critique? Foucault posługuje się francuskim słowem la vertu, co bezpośrednio można przetłumaczyć jako „cnota”. Ponieważ Foucaultowi jednak chodzi o szerokie znaczenie tego terminu, nawiązujące do pewnej orientacji etycznej lub politycznej, oddaję to, posługując się przyjętym w Polsce renesansowym pojęciem virtú, które dla Machiavellego oznaczało mniej więcej tyle, co zdolność do przeciwstawienia się fortunie, odwaga wzięcia spraw we własne ręce itp. Zob. tamże, s. 36.

79 Tenże, Quiest-ce que les Lumières?, s. 571.

80 Tamże, s. 574. 
dotyczącej granic ${ }^{81}$, historyczno-praktycznym sprawdzianie granic, które możemy przekroczyć ${ }^{82}$. Kantowskie negatywne zadanie miałoby być w ten sposób u Foucaulta przekształcone $\mathrm{w}$ zadanie pozytywne. Zamiast zapytywać, z przekraczania jakich granic powinniśmy zrezygnować, należy zapytać o to, jaka część tego, co dane jest nam jako uniwersalne, konieczne, obowiazujace, stanowi to, co pojedyncze, przygodne, arbitralnie ograniczone $e^{83}$. W ten sposób negatywny zakaz wykraczania poza granice rozumu przeradza się w pozytywną refleksję nad możliwym wykroczeniem poza to, co wydawało nam się konieczne i nieuchronne.

Tak określona krytyka praktyczna rezygnuje zatem z transcendentalizmu i uniwersalizmu związanego z projektem Kanta, ale jednocześnie otwiera przed nami pewną przestrzeń wolności. Foucault mówi o swych badaniach jako o historycznej ontologii nas samych. Nie ma ucieczki od historyczności i w tym sensie każda krytyka będzie miała ograniczony i w dużym stopniu przygodny charakter - nie będzie uniwersalna. To wszakże pozwala nam myśleć, że ograniczenia, które są nam narzucone, sytuacja, w jakiej się znaleźliśmy, także nie jest czymś ostatecznym i uniwersalnym, że są one splotem pewnych przygodnych procesów. Oznacza to, że można myśleć inaczej, że można wykonać na sobie pewną „pracę”, a sama ta praca czyni nas w pewnym stopniu „wolnymi istotami". W tym znaczeniu krytyka praktyczna jest postawa eksperymentalna skierowaną na własne ograniczenia, gdyż samo uchwycenie własnego uwarunkowania otwiera możliwość wolności, wolności konkretnej, polegającej na uchwyceniu punktów, w których zmiana jest możliwa i pożadana ${ }^{84}$. Krytyka praktyczna jest zatem skierowana na „siebie”, jest autozwrotną technika siebie $e^{85}$ czy praktykowaniem siebie na sobie [exercise de soi sur soi $]^{86}$ i zakłada możliwość autokreacji podmiotu.

Nie oznacza to jednak nieograniczonej wolności samokształtowania się jednostek, gdyż owo wytwarzanie się podmiotu na poziomie indywidualnym zawsze powiązane jest z technikami rządzenia. W jednym z ostatnich wywiadów Foucault ostrożnie mówi o procesach wyzwolenia [les processus de libération] i stara się je odróżnić od praktyk wolności [les pratiques de liberté]: Zawsze bytem podejrzliwy wobec pojęcia wyzwolenia, gdyż jeśli nie używa sie go z ostrożnościa i w pewnych granicach, ryzykuje się to, że znów wracamy do idei gtoszacej, iż istnieje ludzka natura czy podstawa, która w wyniku pewnych historycznych, ekonomicznych i spotecznych procesów zostata ukryta, wyobcowana czy uwięziona $w$ mechanizmie represji $i$ za jego pomoca. W mysl tej hipotezy należy przede wszystkim przetamać ów represywny impas $i$ cztowiek pojedna się ze soba, odkryje ponownie swa naturę, odzyska tączność ze swym początkiem, ustanowi na nowo petny i pozytywny stosunek z samym sobą. Uważam, że należy się temu doktadnie przyjrzeć ${ }^{87}$.

81 Tamże.

82 Tamże, s. 575.

83 Tamże, s. 574.

84 Tamże.

85 Zob. tenże, Techniki siebie.

86 Tenże, L'êthique du souci de soi comme pratique de la liberté, [w:] tenże, Dits et écrits..., Vol. 4, s. 709.

87 Tamże, s. 710. 
Foucault stwierdza, że nad procesy wyzwolenia przedkłada praktyki wolności, które są niezbędne do tego, by ludzie, którzy zostali „wyzwoleni”, mogli następnie budować i określać formy społecznej egzystencji, które są dla nich do przyjęcia. „Akty wyzwoleńcze" są istotną częścią naszego życia i rzeczywiście występują ${ }^{88}$, nie wystarczą jednak do tego, aby można było określić praktyczne formy wolności. Chociaż są sytuacje, w których stają się one warunkiem praktykowania wolności - Foucault nazywa te sytuacje stanami dominacji - to wyzwolenie zawsze zakłada pojawienie się nowych stosunków władzy, które muszą być kontrolowane przez praktyki wolności. Należy zdaniem Foucaulta odróżnić w społeczeństwie stosunki władzy, które są niezmiernie głęboko w nim zakorzenione, ale równocześnie „ruchome” i możliwe do modyfikowania przez podmioty, od stanów dominacji, gdy podmioty tracą możliwość wpływania na stosunki władzy, które są unieruchomione $i$ zamrożone $e^{89}$. Powinniśmy zatem dążyć do unikania dominacji poprzez praktykowanie wolności.

Foucaultowska idea genealogii, choć wyraźnie dystansuje się od Marksowskiego projektu globalnego wyzwolenia ludzkości, w pewien szczególny sposób reaktywuje jednak Marksowską ideę emancypacji, choć w skromniejszym wymiarze. Sam Marks posługuje się przecież $\mathrm{w}$ swych wczesnych pismach pojęciem emancypacji częściowej (politycznej) ${ }^{90}$, która dopuszcza częściowe, partykularne wyzwolenie, nieznoszące wszelkiej możliwej dominacji, ale z pewnością, by posłużyć się językiem Foucaulta, poszerzające przestrzeń wolności. Marks oczywiście odczuwa wobec tego pojęcia pewien niedosyt, ale traktuje je jak najbardziej poważnie i emancypacja częściowa jest dla niego istotnym elementem walki o emancypację ogólnoludzką. Zarówno jednak emancypacja częściowa, jak i ogólnoludzka mają być dla Marksa praktyką, czyli realną zmianą w świecie. Analogicznie Foucaultowska wolność konkretna oznacza nie tylko wolność w skali ograniczonej, przeciwstawionej wolności w skali globalnej, ale także wolność realna, taką, którą da się zrealizować w praktyce. Nie jest to żaden stan naturalny człowieka, ale konkretny projekt, który trzeba wykonać. W tym sensie Foucault jest zgodny z Marksem, dla którego jakakolwiek teoria ma sens o tyle, o ile zamieni się w praktykę, choć oczywiście do pełnej zgodności będzie im daleko (zwłaszcza z powodu Marksowskiego pojęcia Gattüngswesen - istoty gatunkowej). Emancypacyjne inklinacje Foucaulta ujawniają się raczej w pomniejszych wywiadach, artykułach gazetowych, odezwach politycznych, listach, których zazwyczaj nie analizuje się w kontekście rozważań nad teoretycznym projektem Foucaulta, ale w których pojawia się coś na kształt skromnego projektu politycznego ${ }^{91}$. Jestem przekonany, że projekt ten w dużym stopniu jest inspi-

88 Foucault daje przykład wyzwolenia się kolonii spod władzy kolonizatorów.

89 Zob. M. Foucualt, Lềthique du souci de soi..., s. 711.

90 K. Marks, Przyczynek do krytyki heglowskiej filozofii prawa. Wstęp, [w:] K. Marks, F. Engels, Dzieta, Vol. 1, Warszawa 1962, s. 469.

91 Foucault opowiada się w nich na przykład za złagodzeniem rygoru w więzieniach (M. Foucault, To Punish Is the Most Difficult Thing There Is, [w:] tenże, Power; tenże, Il faut tout repenser la loi et la prison, „Libération” 1981, $15 \mathrm{XII}$ ); protestuje przeciwko karze śmierci (tenże, De la nécessité de mettre un terme à toute peine, „Libération” 1981, 18 VIII); oskarża psychologię i psychiatrię o „wykluczanie” i „represjonowanie” szaleństwa (tenże, Historia szaleństwa w dobie klasycyzmu, przeł. H. Kęszycka, 
rowany myślą Marksa, choć jego siłą jest właśnie to, że został oczyszczony - zgodnie z duchem analizy rekurencyjnej - z tych elementów marksizmu, które nie przystają do współczesności. Dlatego też, z jednej strony, należy przyznać Habermasowi rację, że krytyka Foucaulta nie może być całkowicie pusta, czyli nie może nie odwoływać się do żadnych założeń normatywnych. $Z$ drugiej jednak strony, wydaje mi się, że przedstawiony przez Foucaulta obraz wolności konkretnej świadczy o tym, że po pierwsze, Foucault miał świadomość swoistego normatywnego wymiaru swej koncepcji, a zatem nie był kryptonormatywista, po drugie zaś, że projekt krytyczny nie musi z konieczności odwoływać się do wartości uniwersalnych ${ }^{92}$. Potwierdzeniem tego jest konsekwencja Foucaulta w byciu intellectuel spécifique, krytycznie spoglądającego na dziedzinę, w której się specjalizuje, i poprzez genealogiczne interwencje doprowadzającego do zmiany. Emblematycznymi efektami jego genealogii są reformy więziennictwa we Francji przeprowadzone na początku lat 80 . czy wpływ, jaki Historia szaleństwa wywarła na antypsychiatrię. Są to jasne przykłady siły konkretnego oddziaływania, co do którego nigdy nie będziemy pewni, czy nie przyczyni się w pewnym momencie do globalnej transformacji. To jest oczywiście możliwe, ale nie da się tego z góry założyćc ${ }^{93}$.

\section{BIBLIOGRAFIA}

Ashenden S., Owen D. (red.), Foucault Contra Habermas. Recasting the Dialogue between Genealogy and Critical Theory, London-Thousaund Oaks 1999.

Bachelard G., Filozofia, która mówi nie. Esej o filozofii nowego ducha w nauce, przeł. J. Budzyk, Gdańsk 2000, Minerwa.

Bachelard G., Ksztattowanie się umystu naukowego. Przyczynek do psychoanalizy wiedzy obiektywnej, przeł. i posł. D. Leszczyński, Gdańsk 2002, Minerwa.

wstęp M. Czerwiński, Warszawa 1987; tenże, La Folie n'existe que dans une société, „Le Monde” 1961, 22 VII); pokazuje narodziny medycyny jako efekt transformacji kapitalistycznej (tenże, Narodziny kliniki, przeł. P. Pieniążek, Warszawa 1999; tenże, La Politique de la santé au XVII siècle, [w:] Généalogie des équipements de normalisation: les équipements sanitaires, red. tenże, Fontenay-sur-Bois 1976); domaga się przyznania praw mniejszościom seksualnym (tenże, Un Plaisir si simple, „Le Gai Pied” 1979, nr 1); potępia ekstradycję Klausa Croissanta i obwinia lewicę francuską o „brak reakcji” (tenże, Lettre à quelques leaders de la gauche, „Le Nouvel Observateur” 1977, nr 691); mówi z nadzieją o nowej „logice lewicy" po zwycięstwie we Francji François Mitteranda w 1981 roku (tenże, Est-il donc important du penser?, „Libération” 1981, 30-31 V); krytykuje lewicowy rząd francuski za niechęć do współpracy $\mathrm{z}$ intelektualistami (C. Gordon, Introduction, s. XXXVII); protestuje przeciw łamaniu praw człowieka (M. Foucault, Les Rendez-vous manqués (z P. Bourdieu), „Libération” 1981, 15 XII; tenże, Confronting Governments. Human Rights, [w:] tenże, Power).

92 Podobnie uważa David Owen, który stwierdza, że Focaultowski projekt genealogii, w przeciwieństwie do Habermasowskiego projektu krytyki, który orientuje się na transcedentalny ideat, kieruje się ku ideatowi immanentnemu, opartemu na agonicznym użyciu rozumu, zob. D. Owen, Orientation and Enlightenment. An Essay on Critique and Genealogy, [w:] Foucault Contra Habermas, s. 30.

93 Por. wywiad Foucaulta z Trombadorim - M. Foucault, Remarks on Marx. Conversations With Duccio Trombadori, przel. R.J. Goldstein, J. Cascaito, New York 1991, s. 153-157, Semiotext(e) Foreign Agents Series. 
Bachelard G., Le nouvel esprit scientifique, Paris 1968.

Bachelard G., Le rationalisme appliqué, Paris 1949.

Canguilhem G., La formation du concept de réflexe aux XVIIe et XVIIIe siècles, Paris 1957.

Canguilhem G., Idéologie et Rationalité dans l'histoire des sciences de la vie, Paris 1977, Problèmes et Controverses.

Canguilhem G., Normalne i patologiczne, przeł. i posł. P. Pieniążek, Gdańsk 1999, Minerwa.

Dreyfus H., Rabinow P., Michel Foucault. Beyond Structuralism and Hermeneutics, Chicago 1983.

Eribon D., Michel Foucault. Biografia, przel. J. Levin, Warszawa 2005.

Foucault M., About the Beginning of the Hermeneutics of the Self, „Political Theory” 1993, Vol. 21, nr 2 .

Foucault M., Archeologia wiedzy, przeł. A. Siemek, wstęp J. Topolski, Warszawa 1977, Biblioteka Myśli Wspótczesnej. Plus Minus Nieskończoność.

Foucault M., Bezpieczeństwo, terytorium, populacja. Wyktady w Collège de France 1977/1978, przeł. M. Herer, Warszawa 2010.

Foucault M., Confronting Governments. Human Rights, [w:] tenże, Power, red. J.D. Faubion, przeł. R. Hurley i in., New York 2000.

Foucault M., De la nécessité de mettre un terme à toute peine, „Libération” 1981, 18 VIII.

Foucault M., Dits et écrits, 1954-1988, Vol. 4, red. D. Defert, F. Ewald, Paris 1994, Bibliothèque des Sciences Humaines.

Foucault M., Est-il donc important du penser?, „Libération” 1981, 30-31 V.

Foucault M., Filozofia, historia, polityka. Wybór pism, przeł. D. Leszczyński, L. Rasiński, Warszawa-Wrocław 2000.

Foucault M., La Folie n'existe que dans une société, „Le Monde” 1961, 22 VII.

Foucault M., Il faut tout repenser la loi et la prison, „Libération” 1981, 15 XII.

Foucault M., Historia seksualności, przeł. B. Banasiak, T. Komendant, K. Matuszewski, wstęp T. Komendant, Warszawa 1995, Nowy Sympozjon.

Foucault M., Historia szaleństwa w dobie klasycyzmu, przeł. H. Kęszycka, wstęp M. Czerwiński, Warszawa 1987.

Foucault M., The History of Sexuality, [w:] tenże, Power/Knowledge. Selected Interviews and Other Writings, 1972-1977, ed. C. Gordon, New York 1980.

Foucault M., Les Rendez-vous manqués (z P. Bourdieu), „Libération” 1981, 15 XII.

Foucault M., Lettre à quelques leaders de la gauche, „Le Nouvel Observateur” 1977, nr 691.

Foucault M., Naissance de la biopolitique, [w:] tenże, Résumé des cours, 1970-1982, Paris 1989, Conférences, Essais et Leçons du Collège de France.

Foucault M., Narodziny kliniki, przeł. P. Pieniążek, Warszawa 1999.

Foucault M., Lórdre du discours. Leçon inaugurale au Collège de France prononcée le 2 décembre 1970, Paris 1971.

Foucault M., La Politique de la santé au XVII siècle, [w:] Généalogie des équipements de normalisation: les équipements sanitaires, red. tenże, Fontenay-sur-Bois 1976.

Foucault M., Porzadek dyskursu. Wyktad inauguracyjny wygtoszony w Collège de France 2 grudnia 1970, przeł. M. Kozłowski, Gdańsk 2002, Minerwa.

Foucault M., Power, red. J.D. Faubion, przeł. R. Hurley i in., New York 2000. 
Foucault M., Power/Knowledge. Selected Interviews and Other Writings, 1972-1977, red. C. Gordon, New York 1980.

Foucault M., Qu’est-ce que la critique?, „Bulletin de la Société Française de Philosophie” 1990, Vol. 84.

Foucault M., Qu'est-ce que les Lumières?, [w:] tenże, Dits et écrits, 1954-1988, Vol. 4, red. D. Defert, F. Ewald, Paris 1994, Bibliothèque des Sciences Humaines.

Foucault M., Remarks on Marx. Conversations With Duccio Trombadori, przel. R.J. Goldstein, J. Cascaito, New York 1991, Semiotext(e) Foreign Agents Series.

Foucault M., Réponse à une question, [w:] tenże, Dits et écrits, 1954-1988, Vol. 1, red. D. Defert,

F. Ewald, Paris 1994, Bibliothéque des Sciences Humaines.

Foucault M., Sécurité, territoire, population. Cours au Collège de France (1977-1978), Paris 2004, Hautes Études.

Foucault M., Structuralisme et poststructuralisme (rozmowa z G. Rauletem), „Telos” 1983, Vol. 16, nr 55.

Foucault M., Strukturalizm i poststrukturalizm, [w:] tenże, Filozofia, historia, polityka. Wybór pism, przeł. D. Leszczyński, L. Rasiński, Warszawa-Wrocław 2000.

Foucault M., Subject and Power, [w:] H. Dreyfus, P. Rabinow, Michel Foucault. Beyond Structuralism and Hermeneutics, Chicago 1983.

Foucault M., Techniki siebie, [w:] tenże, Filozofia, historia, polityka. Wybór pism, przeł. D. Leszczyński, L. Rasiński, Warszawa-Wrocław 2000.

Foucault M., To Punish Is the Most Difficult Thing There Is, [w:] tenże, Power, red. J.D. Faubion, przeł. R. Hurley i in., New York 2000.

Foucault M., Truth and Power, [w:] tenże, Power/Knowledge. Selected Interviews and Other Writings, 1972-1977, red. C. Gordon, New York 1980.

Foucault M., Trzeba bronić spoteczeństwa. Wyktady w Collège de France, 1976, przeł. M. Kowalska, Warszawa 1998.

Foucault M., Un Plaisir si simple, „Le Gai Pied” 1979, nr 1.

Foucault M., La Vie. L'expérience et la science, „Revue de Métaphysique et de Morale” 1985, nr 1. Foucault M., Życie. Doświadczenie i nauka, [w:] tenże, Filozofia, historia, polityka. Wybór pism, przeł. D. Leszczyński, L. Rasiński, Warszawa-Wrocław 2000.

Foucault M., L'êthique du souci de soi comme pratique de la liberté, [w:] tenże, Dits et écrits, 1954-1988, Vol. 4, red. D. Defert, F. Ewald, Paris 1994, Bibliothèque des Sciences Humaines.

Fraser N., Foucault on Modern Power. Empirical Insights and Normative Confusions, [w:] Critical Essays on Michel Foucault, red. P. Burke, Aldershot 1992, Critical Thought Series, 2.

Gordon C., Introduction, [w:] M. Foucault, Power, red. J.D. Faubion, przeł. R. Hurley i in., New York 2000.

Habermas J., Filozoficzny dyskurs nowoczesności, przeł. M. Łukasiewicz, Kraków 2000, Horyzonty Nowoczesności, t. 9.

Habermas J., Taking Aim at the Heart of the Present, [w:] Critique and Power. Recasting the Foucault/Habermas Debate, red. M. Kelly, Cambridge, Mass. 1994, Studies in Contemporary German Social Thought.

Hindess B., Filozofie wtadzy. Od Hobbesa do Foucaulta, przeł. D. Leszczyński, L. Rasiński, Warszawa-Wrocław 1999. 
Hoy D.C. (red.), Foucault. A Critical Reader, Oxford-New York 1986.

Kelly M. (red.), Critique and Power. Recasting the Foucault/Habermas Debate, Cambridge, Mass. 1994, Studies in Contemporary German Social Thought.

Kelly M., Foucault, Habermas, and Self-Referentiality of Critique, [w:] Critique and Power. Recasting the Foucault/Habermas Debate, red. tenże, Cambridge, Mass. 1994, Studies in Contemporary German Social Thought.

Leszczyński D., Szlachcic K., Wprowadzenie do francuskiej filozofii nauki. Od Comte’a do Foucaulta, Wrocław 2003, Acta Universitatis Wratislaviensis, nr 2493.

Marks K., Przyczynek do krytyki heglowskiej filozofii prawa. Wstę, [w:] K. Marks, F. Engels, Dzieta, Vol. 1, Warszawa 1962.

Nowicka M., „Urzadzenie”, „zastosowanie”, „uktad” - kategoria dispositif u Michela Foucaulta, jej ttumaczenia i ich implikacje dla postfoucaultowskich analiz wtadzy, „Przegląd Socjologii Jakościowej" 2011, Vol. 7, nr 2.

Owen D., Orientation and Enlightenment. An Essay on Critique and Genealogy, [w:] Foucault Contra Habermas. Recasting the Dialogue between Genealogy and Critical Theory, red. D. Owen, S. Ashenden, London-Thousaund Oaks 1999.

Taylor C., Foucault on Freedom and Truth, [w:] Foucault. A Critical Reader, red. D.C. Hoy, Oxford-New York 1986.

Dr hab. Lotar RASIŃSKI, prof. DSW - pracuje jako profesor nadzwyczajny w Zakładzie Filozofii (Instytut Pedagogiki) Dolnośląskiej Szkoły Wyższej. Obronił doktorat z filozofii na Uniwersytecie Wrocławskim w 2002 r., a w 2013 r. uzyskał tam stopień doktora habilitowanego. W 2014 r. za pracę habilitacyjną został wyróżniony prestiżową Nagrodą Premiera RP. Studiował i prowadził badania między innymi w nowojorskiej New School for Social Research i na University of California w Berkeley. Stypendysta Fundacji Kościuszkowskiej, Komitetu Badań Naukowych i Transregional Center for Democratic Studies (New School). Redaktor naukowy serii wydawniczej Biblioteka Wspótczesnej Myśli Spotecznej przy Wydawnictwie Naukowym DSW. Jego zainteresowania naukowe to współczesna filozofia polityczna, teoria dyskursu, krytyka społeczna i metodologia nauk społecznych. Autor wielu książek, między innymi: Dyskurs i wtadza. Zarys polityki agonistycznej, Śladami Marksa i Wittgensteina. Krytyka spoteczna bez teorii krytycznej, Jezyk, dyskurs, spoteczeństwo. Zwrot lingwistyczny w filozofii spotecznej (redaktor) i Ludwig Wittgenstein - konteksty i konfrontacje (redaktor, z P. Dehnelem); autor licznych tłumaczeń z języków angielskiego i francuskiego oraz kilkudziesięciu artykułów w czasopismach specjalistycznych. 